\title{
A CLINICAL OBSERVATIONAL STUDY OF OROCUTANEOUS MANIFESTATIONS IN PEOPLE LIVING WITH HIV/AIDS
}

Nayeem Sadath Haneef ${ }^{1}$

1 Professor and HOD, Department of Dermatology, Venereology \& Leprosy, Deccan College of Medical Sciences, Hyderabad.

\section{ABSTRACT}

\section{CONTEXT}

India has third highest prevalence of HIV/AIDS patients in the world. There were an estimated 2.31 million (1.8-2.9 million) people living with HIV/AIDS (PLHA) in India in 2007, whereas, slightly declining to 2.1 million in 2013. Early diagnosis of this infection is important not only for effective treatment of the affected patient but also for prevention of further transmission to others. Cutaneous manifestations can be an early pointer to this infection and hence play an important role in the control of HIV/AIDS. They are also useful for clinical staging (WHO staging) of these patients for therapeutic and prognostic purposes, especially in the absence of sophisticated laboratory facilities, as in many parts of India. The profile of cutaneous manifestations in HIV/AIDS patients varies according to their CD4 count. Some of these manifestations are also unique to certain geographic areas.

\section{AIMS}

To study the local pattern of cutaneous and oral manifestations in people living with HIV/AIDS.

\section{SETTINGS AND DESIGN}

A clinical, observational study was conducted among patients consulting Dermatology, Venereology and Leprosy Department of a Tertiary Care, Medical College Hospital in Telangana State, South India.

\section{METHODS AND MATERIAL}

A total of 120 patients of HIV/AIDS, detected by ELISA or other tests, belonging to all age groups and sexes were included.

\section{RESULTS}

Most common cutaneous manifestations observed were pruritic papular rash (20.8\%), scabies (12.5\%), folliculitis (11.7\%), dermatophytosis $(10.8 \%)$, xerosis $(10.8 \%)$, seborrhoeic dermatitis (10\%), drug rashes $(9.2 \%)$, candidal vaginitis (5\%), molluscum contagiosum (4.2\%), and herpes genitalis (3.3\%). Oral candidiasis was the commonest oral mucosal manifestation (37.5\%).

\section{CONCLUSION}

Most of the cutaneous and oral manifestations found in PLHA were concurrent with previous studies, but high incidence of pruritic papular rash is an interesting finding of this study.

\section{KEYWORDS}

Cutaneous Manifestations, Oral Manifestations, HIV/AIDS, PLHA.

HOW TO CITE THIS ARTICLE: Haneef NS. A clinical observational study of orocutaneous manifestations in people living with HIV/AIDS. J. Evolution Med. Dent. Sci. 2016;5(35):2042-2048, DOI: 10.14260/jemds/2016/479

\section{INTRODUCTION}

AIDS (Acquired Immuno Deficiency Syndrome) represents the late clinical stage of infection with HIV (Human Immunodeficiency Virus), which incapacitates the immune system by mainly affecting CD4 T cells. First recognised in 1981, this disease has reached epidemic proportions in many parts of the world, especially Sub-Saharan Africa. ${ }^{1}$ India has third highest prevalence of HIV/AIDS patients in the world, next only to South Africa and Nigeria. Estimated prevalence of people living with HIV/AIDS (PLHA) in India was 2.31 million (1.8-2.9 million) in India in 2007.2 The prevalence is declining in recent years, with an estimated prevalence of 2.1 million in 2013.

Financial or Other, Competing Interest: None

Submission 19-03-2016, Peer Review 13-04-2016,

Acceptance 18-04-2016, Published 02-05-2016.

Corresponding Author:

Dr. Nayeem Sadath Haneef,

7/202, Kalyani, Sahara States,

Mansoorabad, LB Nagar,

Hyderabad-500068,

Telangana State, India.

E-mail:dr_nayeemsadath@yahoo.co.in

DOI: $10.14260 /$ jemds/2016/479
Andhra Pradesh and Maharashtra have highest number of HIV/AIDS patients in India. ${ }^{3}$ Though there is no curative therapy for this deadly disease as yet, aggressive antiretroviral therapy at seroconversion stage has been found to protect the activated HIV specific CD4 T cells from being infected by the HIV. Early diagnosis of this infection is important not only for effective treatment of the affected patient but also for prevention of further transmission to the partner(s) and nonvenereal transmission to others by blood transfusion, sharing of injection needles, etc.

Cutaneous manifestations can be an early pointer to this infection and hence play an important role in the control of HIV/AIDS. ${ }^{3}$ They are also useful for clinical staging (WHO staging) of these patients for therapeutic and prognostic purposes, especially in the absence of sophisticated laboratory facilities, as in many parts of India. In view of these factors, we conducted a clinical study to evaluate the local pattern of cutaneous manifestations in HIV infected persons in our part of India. 


\section{MATERIALS AND METHODS}

\section{Objectives}

To study the local pattern of cutaneous manifestations in people living with HIV/AIDS (PLHA).

\section{Study Design}

Clinical observational study.

\section{Setting}

Dermatology, Venereology and Leprosy Department of a Tertiary Care Hospital attached to a postgraduate training institute in Telangana State of India.

\section{Duration of the Study \\ 2 years.}

\section{Patients}

120 patients $(n=120)$ having HIV/AIDS were included. The following criteria were used.

\section{Inclusion Criteria}

All patients who are positive for HIV 1 or 2 , as detected by ELISA or other tests were included in the study. Patients of all age groups and sexes were included.

\section{Exclusion Criteria}

Nil.

\section{METHODS}

Detailed history was elicited including pre/extramarital unprotected sexual exposure, onset, evolution and duration of skin lesions, treatment history etc. Complete general physical, systemic and cutaneous examinations were carried out and findings recorded in a proforma. CD4 count and any other relevant tests (eg: skin biopsy) were done. The WHO clinical stage and CD4 count of each patient were noted.

\section{RESULTS}

Total number of patients enrolled in the study was 120. Most patients belonged to 31-40 years age group (46 patients; $38.3 \%$ ) followed by $21-30$ years age group (42 patients; $35 \%$ ) (Table 1). Out of 120 patients, $62(51.7 \%)$ were males and 58 (48.3\%) were females (table 2). Apart from housewives, who constituted 39 (32.5\%) patients, most common occupation of patients was farming - 28 (23.3\%) patients, followed by labourers $-22(18.3 \%)$ and vendors - 13 (10.8\%) patients (Table 3).

CD4 count was more than 500 cells $/ \mathrm{mm}^{3}$ in $2(1.7 \%)$ patients whereas $201-500$ cells $/ \mathrm{mm}^{3}$ in 49 (40.8\%), 50-200 cells $/ \mathrm{mm}^{3}$ in $66(55 \%)$ and below 50 cells $/ \mathrm{mm}^{3}$ in $3(2.5 \%)$ of patients (table 4). There were no patients having WHO clinical stage I. WHO stage II disease was seen in 68 (56.7\%) patients, stage III in $47(39.1 \%)$ patients and stage IV in $5(4.2 \%)$ patients (Table 5).

All the patients included in the study had skin, hair, nail or oral mucosal lesions. Most common skin condition noted was pruritic papular rash (figure 1), which was seen in 25 (20.8\%) patients (table 6). This was followed by infections namely scabies in 15 (12.5\%), folliculitis in 14 (11.7\%) including dissecting cellulitis of scalp (Figure 2), dermatophytosis (figure $3 \& 4)$ in $13(10.8 \%)$ patients. Norwegian scabies was seen in 2 out of 15 scabies patients (Figures 5, 6, 7, 8 \& 9).
Xerosis including ichthyosis was seen in $13(10.8 \%)$ patients. Seborrhoeic dermatitis was seen in 12 (10\%) patients. Herpes zoster in 5 patients, 2 of which had multidermatomal involvement and ophthalmic/maxillary region was affected in 1 patient each. Other less commonly seen infections were herpes labialis, warts, molluscum contagiosum, impetigo, DCPA (Dermatitis cruris pustulosa et atrophicans), folliculitis decalvans, pityriasis versicolor, sporotrichosis, and leprosy. Leprosy was seen in $2(1.7 \%)$ patients and both had type 1 reaction probably due to IRIS (Immune restoration inflammatory syndrome). Less common non-infectious dermatoses included Addisonian pigmentation, psoriasis, lichen planus, vitiligo, asteatotic eczema, phytodermatitis, keratolysis exfoliativa, miliaria pustulosa, erythema nodosum, neurofibromatosis and erythroderma.

Drug rash was seen in 11 (9.2\%) of patients (Table 6), of which $8(6.7 \%)$ had maculopapular drug rash, $2(1.7 \%)$ had Stevens-Johnson syndrome and $1(0.8 \%)$ had lichenoid drug reaction (Table 11). Commonest cause of drug reactions was nevirapine (9 cases), whereas co-trimoxazole and antitubercular therapy was responsible for 1 case of maculopapular drug rash and lichenoid drug rash respectively (Table 11).

Most common oral mucosal condition was candidiasis, seen in 45 (37.5\%) patients, of which 6 had oesophageal involvement (Table 7, figure 10). Other rarer conditions were pigmentation, glossitis, nutritional angular cheilitis, herpetic stomatitis, aphthous stomatitis, oral lichen planus and StevenJohnson syndrome.

Sexually transmitted infections were found in 20 $(16.7 \%)$ patients of which commonest were candidal vaginitis in $6(5 \%)$, molluscum contagiosum in $5(4.2 \%)$ and herpes genitalis in 4 (3.3\%) patients (table 8). Chancroid (figure 12), lymphogranuloma venereum, nongonococcal urethritis, trichomonal vaginitis and pelvic inflammatory disease were rarely observed STIs.

Scarring alopecia over the scalp due to folliculitis decalvans was found in $2(1.7 \%)$ patients (table 9). Pallor of the nails in 7 (5.8\%) patients, melanonychia (Figure 12) in 2 $(1.7 \%)$ and total dystrophic onychomycosis in $1(0.8 \%)$ patients were the various nail changes observed (Table 10).

Most of the conditions described above were observed in both WHO stage II and WHO stage III patients and also associated with variable CD4 count ranging from below 50 cells $/ \mathrm{mm}^{3}$ to above 500 cells $/ \mathrm{mm}^{3}$. However, in case of WHO stage IV patients, more severe manifestations like moderateto-severe seborrhoeic dermatitis, Norwegian (crusted) scabies, extensive dermatophytosis and multidermatomal herpes zoster were observed (Table 12).

\begin{tabular}{|c|c|}
\hline Age Groups (Years) & No. of Patients \\
\hline $1-10$ & 4 \\
\hline $11-20$ & 4 \\
\hline $21-30$ & 42 \\
\hline $31-40$ & 46 \\
\hline $41-50$ & 15 \\
\hline $51-60$ & 7 \\
\hline $61-70$ & 2 \\
\hline \multicolumn{2}{|c|}{ Total } \\
\hline \multicolumn{2}{|c|}{ Table 1: Age Distribution (n=120) } \\
\hline
\end{tabular}




\begin{tabular}{|c|c|}
\hline Sex & No. of Patients \\
\hline Male & 62 \\
\hline Female & 58 \\
\hline Total & $\mathbf{1 2 0}$ \\
\hline \multicolumn{2}{|c|}{ Table 2: Sex Distribution $(\mathbf{n = 1 2 0})$} \\
\hline
\end{tabular}

\begin{tabular}{|c|c|}
\hline Occupation & No. of Patients \\
\hline Housewife & 39 \\
\hline Farmer & 28 \\
\hline Labourer & 22 \\
\hline Business/vendor & 13 \\
\hline Student & 6 \\
\hline Driver & 4 \\
\hline Mechanic & 2 \\
\hline Teacher & 2 \\
\hline Supervisor & 1 \\
\hline Salesgirl & 1 \\
\hline Tailor & 1 \\
\hline Laundry & 1 \\
\hline Total & $\mathbf{1 2 0}$ \\
\hline \multicolumn{2}{|c|}{ Table 3: Occupation (n=120) } \\
\hline \multicolumn{2}{|c}{}
\end{tabular}

\begin{tabular}{|c|c|c|}
\hline $\begin{array}{c}\text { Sl. } \\
\text { No. }\end{array}$ & CD 4 Count (Range) & No. of Patients \\
\hline 1 & $>500$ & 2 \\
\hline 2 & $201-500$ & 49 \\
\hline 3 & $50-200$ & 66 \\
\hline 4 & $<50$ & 3 \\
\hline \multicolumn{2}{|r|}{ Table 4: Distribution of Patients by CD4 Count (n=120) } \\
\hline
\end{tabular}

\begin{tabular}{|c|c|c|}
\hline Sl. No. & WHO Clinical Stage & No. of Patients \\
\hline 1 & I & - \\
\hline 2 & II & 68 \\
\hline 3 & III & 47 \\
\hline 4 & IV & 5 \\
\hline \multicolumn{3}{|c|}{$\begin{array}{c}\text { Table 5: Distribution of Patients by } \\
\text { WHO Clinical Stage (n=120) }\end{array}$} \\
\hline
\end{tabular}

\begin{tabular}{|c|c|c|}
\hline $\begin{array}{c}\text { Sl. } \\
\text { No. }\end{array}$ & Skin Disease & $\begin{array}{c}\text { No. of } \\
\text { Patients }\end{array}$ \\
\hline 1 & Pruritic papular rash & 25 \\
\hline 2 & Scabies & 15 \\
\hline 3 & Folliculitis/furunculosis & 14 \\
\hline 4 & Tinea (dermatophytosis) & 13 \\
\hline 5 & Xerosis/ichthyosis & 13 \\
\hline 6 & Seborrhoeic dermatitis & 12 \\
\hline 7 & Drug rash & 11 \\
\hline 8 & Herpes zoster & 5 \\
\hline 9 & Molluscum contagiosum & 3 \\
\hline 10 & Non healing ulcer due to furuncle & 2 \\
\hline 11 & Impetigo & 2 \\
\hline 12 & Dermatitis cruris pustulosa et & 2 \\
\hline 13 & atrophicans & 2 \\
\hline 14 & Folliculitis decalvans & 2 \\
\hline 15 & Leprosy & 2 \\
\hline 16 & Addisonian pigmentation & 2 \\
\hline 17 & Lichen planus & 1 \\
\hline
\end{tabular}

\begin{tabular}{|l|c|c|}
\hline 18 & Vitiligo & 1 \\
\hline 19 & Phytodermatitis & 1 \\
\hline 20 & Asteatotic eczema & 1 \\
\hline 21 & Warts (nongenital) & 1 \\
\hline 22 & Herpes labialis & 1 \\
\hline 23 & Pityriasis versicolor & 1 \\
\hline 24 & Sporotrichosis & 1 \\
\hline 25 & Keratolysis exfoliativa & 1 \\
\hline 26 & Erythroderma & 1 \\
\hline 27 & Miliaria pustulosa & 1 \\
\hline 28 & Neurofibromatosis & 1 \\
\hline 29 & Erythema nodosum & 1 \\
\hline \multicolumn{2}{|c|}{ Total } & $\mathbf{1 3 8}$ \\
\hline & Table 6: Skin Diseases \\
\hline
\end{tabular}

\begin{tabular}{|c|c|c|}
\hline $\begin{array}{c}\text { Sl. } \\
\text { No. }\end{array}$ & Oral Mucosal Diseases & No. of Patients \\
\hline 1 & Oral candidosis & 45 \\
\hline 2 & Pigmentation & 5 \\
\hline 3 & Glossitis & 3 \\
\hline 4 & Angular cheilitis (nutritional) & 2 \\
\hline 5 & Herpetic stomatitis & 2 \\
\hline 6 & Aphthous stomatitis/ulcers & 1 \\
\hline 7 & Oral lichen planus & 1 \\
\hline 8 & Stevens - Johnson syndrome & 1 \\
\hline \multicolumn{2}{|c|}{ Total } \\
\hline \multicolumn{2}{|c|}{ Table 7: Oral Mucosal Diseases } \\
\hline
\end{tabular}

\begin{tabular}{|c|c|c|}
\hline $\begin{array}{c}\text { Sl. } \\
\text { No. }\end{array}$ & $\begin{array}{c}\text { Sexually Transmitted } \\
\text { Infections }\end{array}$ & $\begin{array}{c}\text { No. of } \\
\text { Patients }\end{array}$ \\
\hline 1 & Candidal vaginitis & 6 \\
\hline 2 & Molluscum contagiosum & 5 \\
\hline 3 & Herpes genitalis & 4 \\
\hline 4 & Chancroid & 1 \\
\hline 5 & Lymphogranuloma venereum & 1 \\
\hline 6 & Nongonococcal urethritis & 1 \\
\hline 7 & Trichomonas vaginitis & 1 \\
\hline 8 & Pelvic inflammatory disease & 1 \\
\hline \multicolumn{2}{|c|}{ Total } & $\mathbf{2 0}$ \\
\hline \multicolumn{2}{|c|}{ Table 8: Sexually Transmitted Infections } \\
\hline
\end{tabular}

\begin{tabular}{|c|c|c|}
\hline $\begin{array}{c}\text { Sl. } \\
\text { No. }\end{array}$ & Hair Disorders & $\begin{array}{c}\text { No. of } \\
\text { Patients }\end{array}$ \\
\hline 1 & $\begin{array}{c}\text { Scarring alopecia (Folliculitis } \\
\text { decalvans) }\end{array}$ & 2 \\
\hline \multicolumn{2}{|c|}{ Table 9: Hair Disorders } \\
\hline
\end{tabular}

\begin{tabular}{|c|c|c|}
\hline $\begin{array}{c}\text { Sl. } \\
\text { No. }\end{array}$ & Nail Disorders & $\begin{array}{c}\text { No. of } \\
\text { Patients }\end{array}$ \\
\hline 1 & Pallor (Leukonychia) & 7 \\
\hline 2 & Melanonychia & 2 \\
\hline 3 & $\begin{array}{c}\text { Total dystrophic } \\
\text { onychomycosis }\end{array}$ & 1 \\
\hline \multicolumn{2}{|c|}{ Table 10:: Nail Disorders } \\
\hline
\end{tabular}




\begin{tabular}{|c|c|c|}
\hline $\begin{array}{c}\text { Type of Drug } \\
\text { Reaction }\end{array}$ & $\begin{array}{c}\text { No. of } \\
\text { Patients }\end{array}$ & Causative Drugs \\
\hline $\begin{array}{c}\text { Maculopapular } \\
\text { drug rash }\end{array}$ & 8 & $\begin{array}{c}\text { (Nevirapine - 7; } \\
\text { cotrimoxazole -1) }\end{array}$ \\
\hline $\begin{array}{c}\text { Stevens - Johnson } \\
\text { syndrome }\end{array}$ & 2 & Nevirapine \\
\hline $\begin{array}{c}\text { Lichenoid drug } \\
\text { reaction }\end{array}$ & 1 & ATT \\
\hline \multicolumn{2}{|c|}{ Table 11: Drug Reactions } \\
\hline
\end{tabular}

\begin{tabular}{|c|c|c|}
\hline $\begin{array}{c}\text { Sl. } \\
\text { No. }\end{array}$ & Dermatoses & $\begin{array}{c}\text { No. of } \\
\text { Patients }\end{array}$ \\
\hline 1 & $\begin{array}{c}\text { Seborrhoeic dermatitis (Moderate } \\
\text { to severe) }\end{array}$ & 2 \\
\hline 2 & Norwegian scabies & 1 \\
\hline 3 & Herpes zoster (Multidermatomal) & 1 \\
\hline 4 & Warts (Extensive) & 1 \\
\hline 5 & Tinea faciei et corporis (Extensive) & 1 \\
\hline \multicolumn{3}{|c|}{ Table 12: Dermatoses Observed In } \\
WHO Stage IV Disease (Advanced HIV) \\
\hline
\end{tabular}

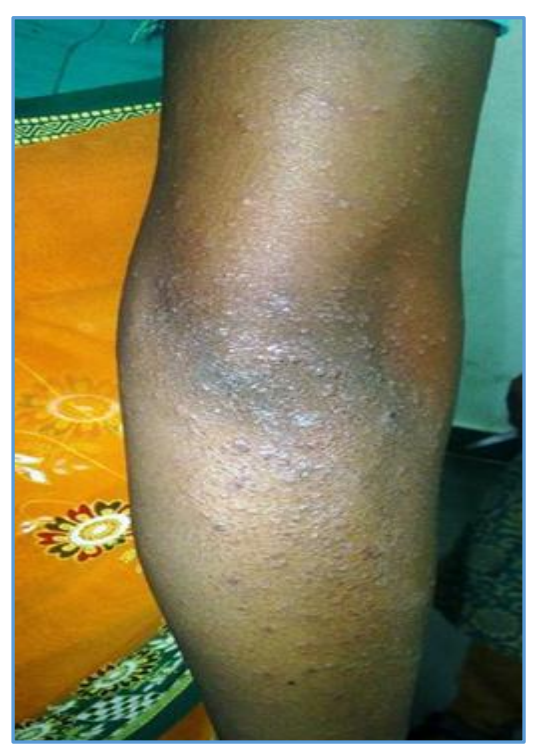

Fig. 1: Pruritic Papular Rash of HIV
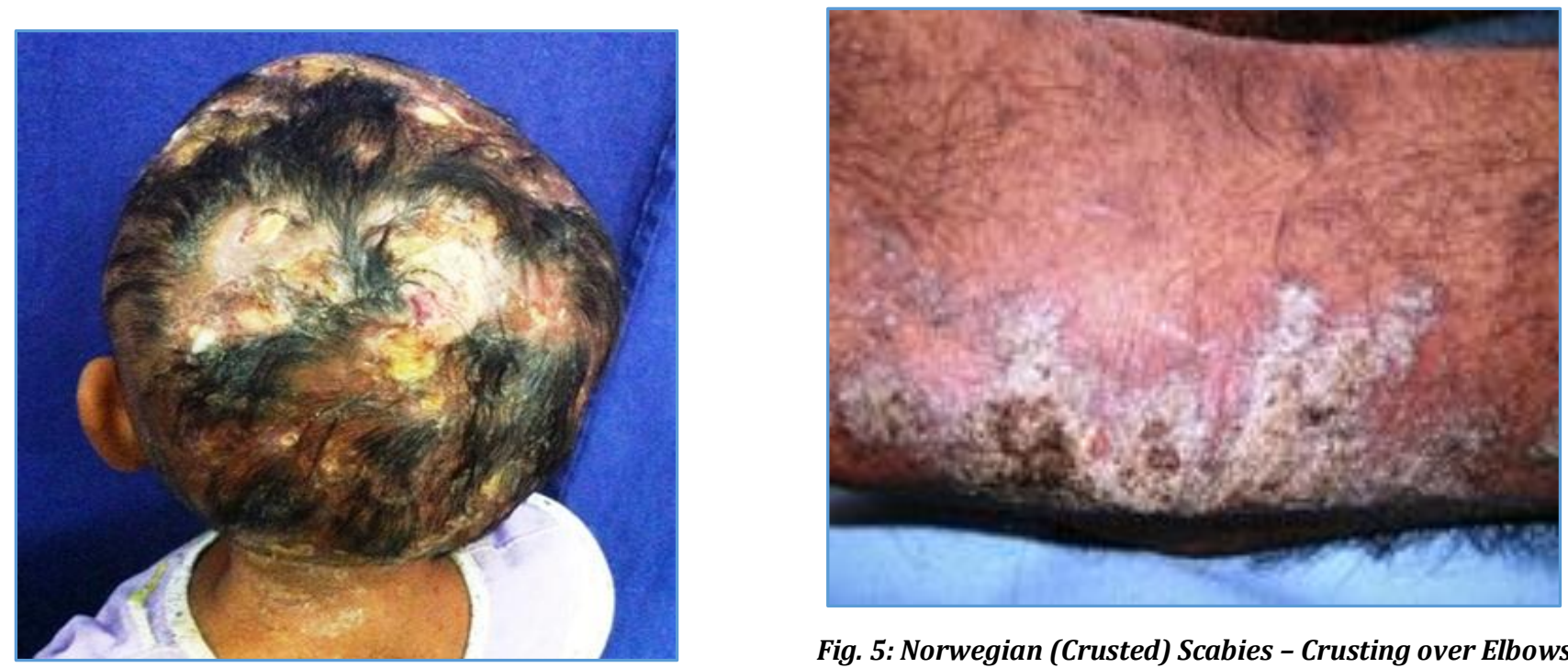

Fig. 5: Norwegian (Crusted) Scabies - Crusting over Elbows

Fig. 2: Dissecting Cellulitis of Scalp in a Young Girl 


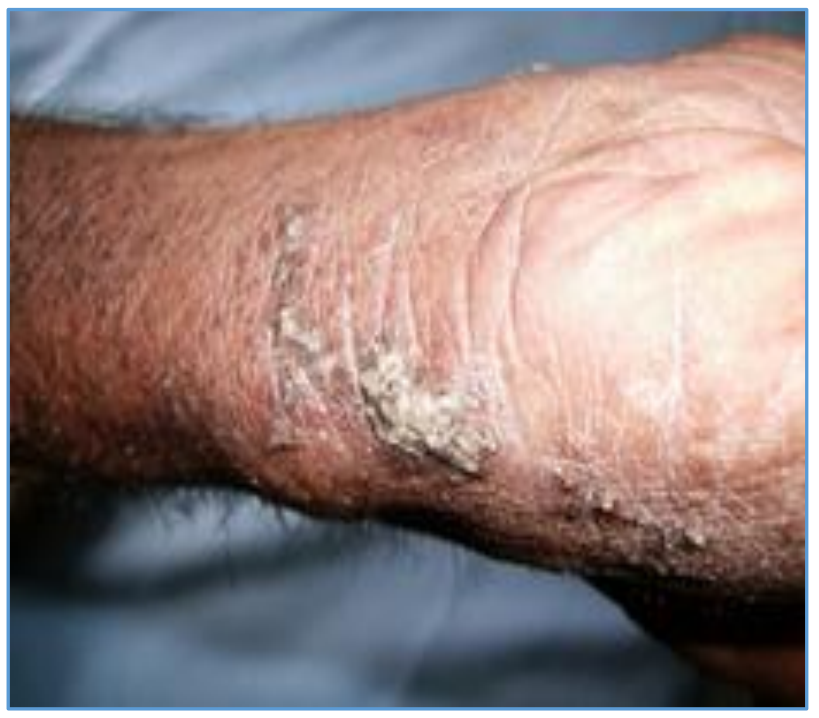

Fig. 6: Norwegian (Crusted) Scabies - Crusting Near Wrists

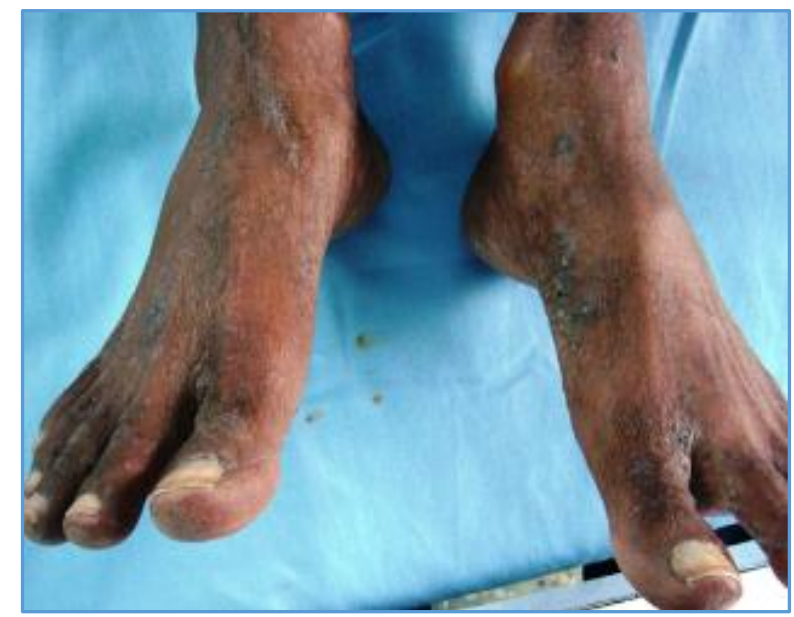

Fig. 7: Norwegian (Crusted) Scabies - Crusting Over Feet Including Toe Web Spaces

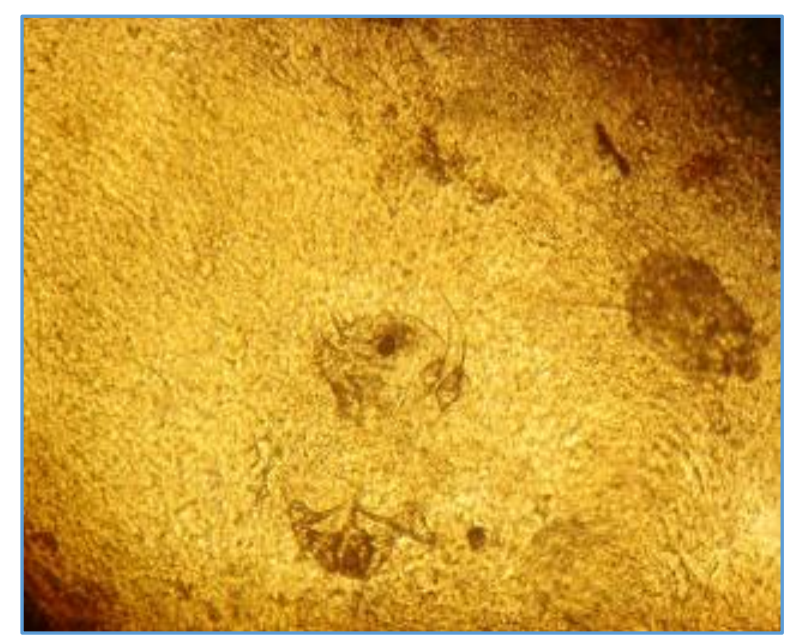

Fig. 8: Numerous Sarcoptes Scabiei Mites in Norwegian Scabies Patient

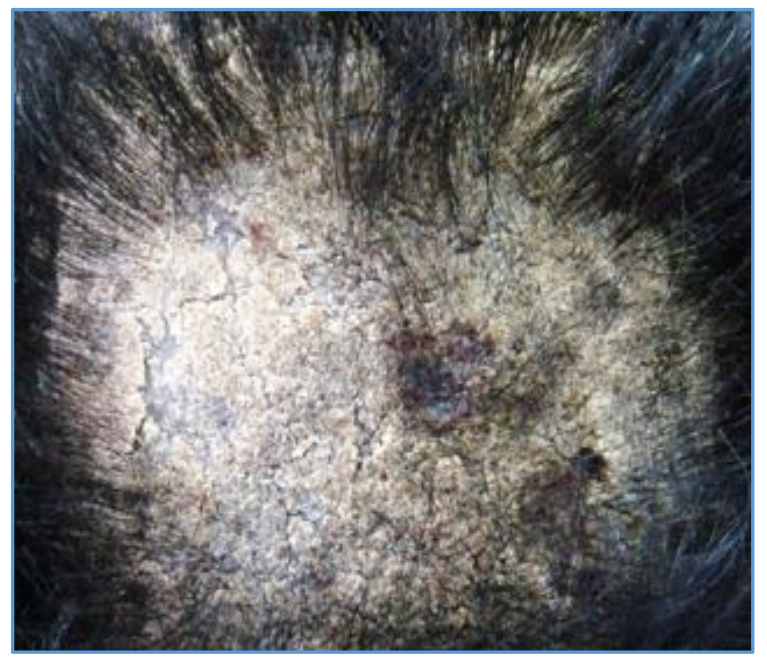

Fig. 9: Severe Seborrhoeic Dermatitis with Crusted Scabies

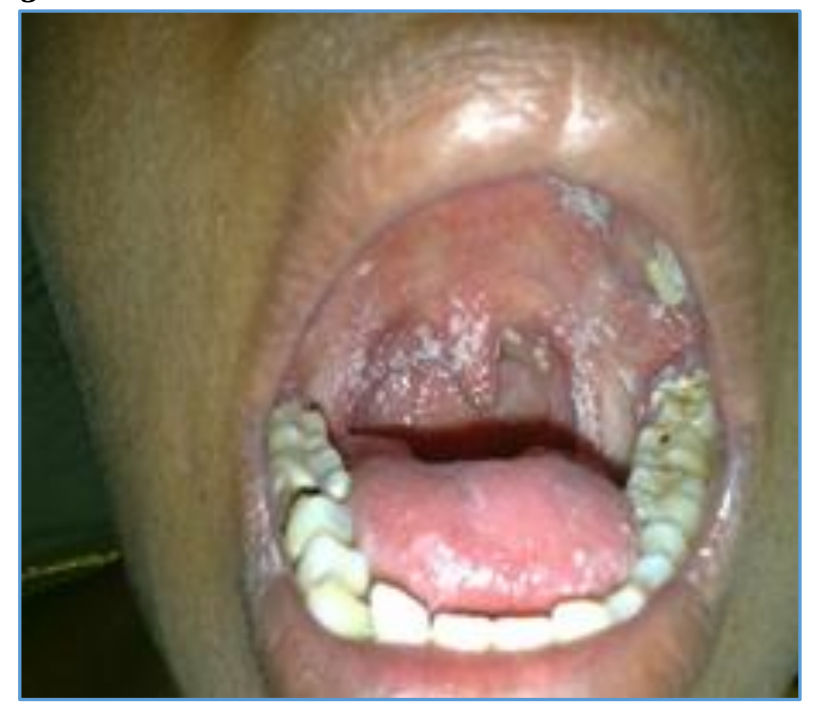

Fig. 10: Oral Candidiasis

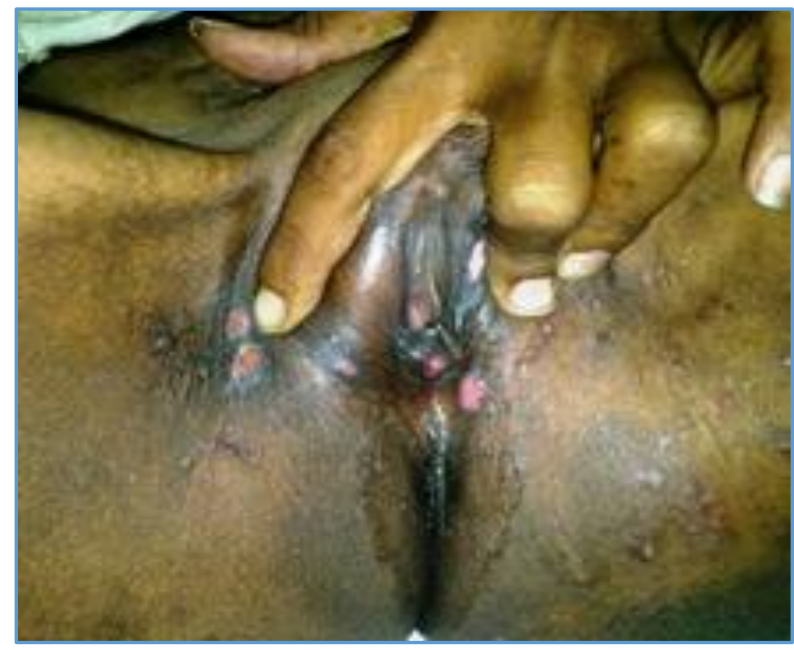

Fig. 11: Multiple Chancroid Genital Ulcers - Caused by Haemophilus Ducreyi, along with Tinea Cruris 


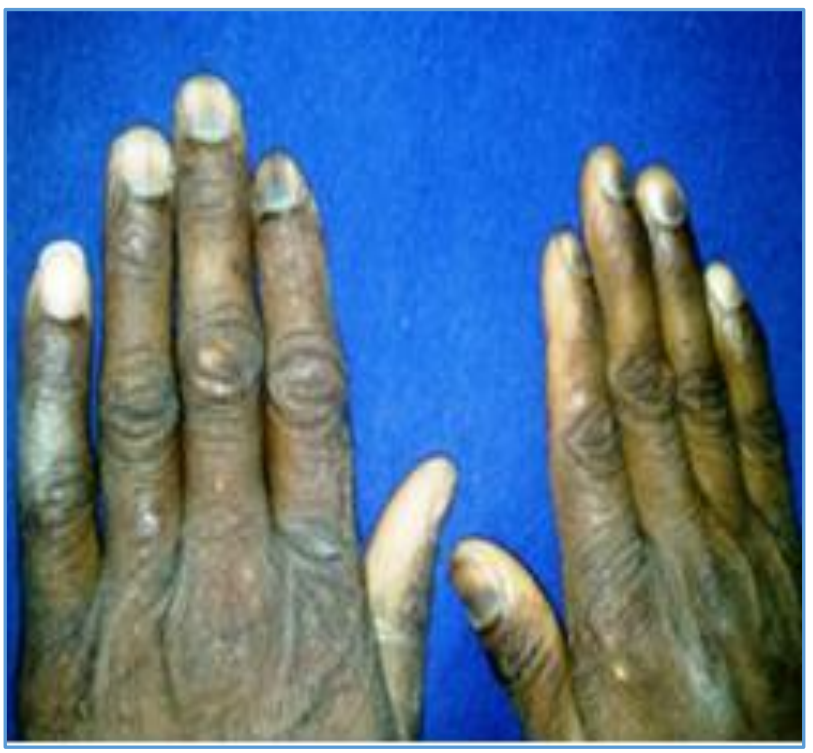

Fig. 12: Melanonychia, which may occur due to HIV Infection Itselfor Due To Drugs like Zidovudine

\section{DISCUSSION}

Cutaneous manifestations are found in every stage of HIV infection. ${ }^{1}$ The first stage, i.e. acute retroviral syndrome/primary HIV infection, which manifests 2-4 weeks after the initial infection, may present with erythematous maculopapular rash, mucocutaneous ulcerations and thrush involving mouth or genitals. In the second stage (Asymptomatic stage), though only persistent generalised lymphadenopathy may be present, occasionally one may have scars from previous genital ulcer or other asymptomatic dermatological manifestations. During the symptomatic HIV infection and AIDS, the skin and mucous membranes are predominantly involved. Widespread seborrhoeic dermatitis is the earliest manifestation. Numerous opportunistic infections, infestations and malignancies are known to occur apart from diseases like psoriasis, ichthyosis, pruritic papular rash, hair and nail abnormalities. Common diseases may present with atypical features and uncommon diseases may occur more commonly in HIV/AIDS patients than general population. Moreover, response to treatment may be poor making these disorders more persistent than usual. Many of these conditions are pathognomonic of HIV/AIDS, thereby emphasising the importance of cutaneous manifestations. ${ }^{2,3}$

Among fungal infections, oral candidiasis is one of the commonest associations of HIV/AIDS occurring in $20-72 \%$ of patients. Later oesophageal, tracheobronchial or genital candidiasis may set in. Several studies indicate candidiasis to be a marker of rapid HIV disease progression and death. ${ }^{4}$ Dermatophytic infections of various sites of the body and other fungal infections like pityriasis versicolor occur more frequently and more severely. Deep fungal infections like sporotrichosis, histoplasmosis, aspergillosis, penicilliosis, coccidioidomycosis are more commonly seen. Some of these conditions may present with umbilicated papules resembling molluscum contagiosum. ${ }^{2}$

Bacterial infections caused by virtually any bacteria is possible in HIV/AIDS. Folliculitis, furunculosis, impetigo, abscesses, cellulitis, erysipelas and various other morphologies can be seen. Cutaneous tuberculosis or other atypical mycobacterial infections do not appear to be more frequent as is the case with leprosy. ${ }^{5}$ However, various studies have shown an increased incidence of type 1 reaction in cases of HIV associated leprosy, which very often occurs as a result of IRIS (Immune reconstitution inflammatory syndrome) where patients put on antiretroviral treatment may develop new inflammatory skin conditions due to improvement of immunity. ${ }^{6}$ Bacillary angiomatosis caused by Bartonella henselae or Bartonella Quintana is one of the pathognomonic conditions of HIV.1,2

Varicella occurring in HIV may be more severe and protracted and so is the case with herpes simplex (labialis/genitalis), herpes zoster, warts and molluscum contagiosum. Herpes zoster may be multidermatomal, disseminated or recurrent or may be associated with haemorrhagic lesions, severe postherpetic neuralgia or painless lesions. Molluscum contagiosum may involve atypical sites like periorbital area and there may be giant lesions measuring more than $1 \mathrm{~cm}$ in size. Similarly, giant genital warts known as Bushcke-Lowenstein tumour may occur, which is a premalignant lesion. Oral hairy leukoplakia caused by Epstein Barr virus is another pathognomonic condition seen in HIV/AIDS. ${ }^{1,2}$

Scabies occurs more commonly and crusted or Norwegian scabies may be seen in patients with CD counts less than 150 cells $/ \mathrm{mm}^{3}$. Pediculosis and Demodex folliculitis occur more frequently.1,2 Inflammatory dermatoses like psoriasis, lichen planus, seborrhoeic dermatitis occur more commonly and with increased severity. Particularly, seborrhoeic dermatitis is the earliest cutaneous manifestation to occur as well as one of the commonest manifestation occurring in up to $83 \%$ of the patients. Its severity is known to increase with progression of HIV infection. Similarly pruritic popular rash is one of the earliest manifestations. ${ }^{1,2}$

Drug eruptions are also more common in HIV disease due to deficient drug detoxification mechanisms as well as due to the increased need for multiple drugs to treat various diseases in HIV patients. Common drugs associated are cotrimoxazole, nevirapine and antitubercular drugs. Various morphologies ranging from morbilliform rash to StevensJohnson syndrome and toxic epidermal necrolysis may occur. Opportunistic malignancies such as Kaposi's sarcoma and Non-Hodgkin's lymphoma are not as common in India as in Western countries. ${ }^{7}$

Hair changes such as hypertrichosis of the eyelashes, thinning of hair, premature greying, alopecia may occur in HIV infection. Nail changes such as onychomycosis, transverse or longitudinal ridging, paronychia, pigmentation etc may occur. ${ }^{1,2}$ In our study, all the patients included in the study had skin, hair, nail or oral mucosal lesions. Most common skin condition noted was pruritic papular rash, which was seen in $25(20.8 \%)$ patients (table 6$)$. This was followed by infections namely scabies in 15 (12.5\%), folliculitis in $14(11.7 \%)$, dermatophytosis in 13 (10.8\%) of patients. Xerosis including ichthyosis was seen in $13(10.8 \%)$ patients. Seborrhoeic dermatitis was seen in $12(10 \%)$ patients.

Other less commonly seen infections were herpes zoster, herpes labialis, warts, molluscum contagiosum, impetigo, DCPA (dermatitis cruris pustulosa et atrophicans), folliculitis decalvans, pityriasis versicolor, sporotrichosis and leprosy. Leprosy was seen in $2(1.7 \%)$ patients and both had type 1 reaction probably due to IRIS (Immune restoration inflammatory syndrome). Less common noninfectious dermatoses included Addisonian pigmentation, psoriasis, 
lichen planus, vitiligo, asteatotic eczema, phytodermatitis, keratolysis exfoliativa, miliaria pustulosa, erythema nodosum, neurofibromatosis and erythroderma.

Most common oral mucosal condition was candidiasis, seen in $45(37.5 \%)$ patients (Table 7). Other rarer conditions were pigmentation, glossitis, nutritional angular cheilitis, herpetic stomatitis, aphthous stomatitis, oral lichen planus and Steven-Johnson syndrome.

Sexually transmitted infections were found in 20 (16.7\%) patients of which commonest were candidal vaginitis in $6(5 \%)$, molluscum contagiosum in $5(4.2 \%)$ and herpes genitalis in $4(3.3 \%)$ patients (Table 8). Chancroid, lymphogranuloma venereum, nongonococcal urethritis, trichomonal vaginitis and pelvic inflammatory disease were rarely observed STIs.

Scarring alopecia over the scalp due to folliculitis decalvans was found in $2(1.7 \%)$ patients (Table 9). Pallor of the nails in $7(5.8 \%)$ patients, melanonychia in $2(1.7 \%)$ and total dystrophic onychomycosis in $1(0.8 \%)$ patients were the various nail changes observed (Table 10).

Drug rash was seen in $11(9.2 \%)$ of patients (table 6), of which 8 (6.7\%) had maculopapular drug rash, 2 (1.7\%) had Stevens-Johnson syndrome and $1(0.8 \%)$ had lichenoid drug reaction (Table 11). Commonest cause of drug reactions was nevirapine (9 cases), whereas co-trimoxazole and antitubercular therapy was responsible for 1 case of maculopapular drug rash and lichenoid drug rash respectively (Table 11).

Most of the conditions described above were observed in both WHO stage II and WHO stage III patients and also associated with variable CD4 count ranging from below 50 cells $/ \mathrm{mm}^{3}$ to above 500 cells $/ \mathrm{mm}^{3}$. However, in case of WHO stage IV patients, more severe manifestations like moderateto-severe seborrhoeic dermatitis, Norwegian (Crusted) scabies, extensive dermatophytosis and multidermatomal herpes zoster were observed (Table 12). This finding reinforces the importance of evaluating cutaneous markers in various stages for prognostic purposes.

The findings of our study were concurrent with previously reported studies in the literature. Many cases showed opportunistic skin infections or inflammatory skin conditions apart from few cases of oral mucosal involvement, sexually transmitted infections and drug reactions. Opportunistic malignancies like Kaposi's sarcoma were not seen, as reported in few other Indian studies since it is believed that lifespan in Indian patients of HIV/AIDS is so short that they do not live till such time that opportunistic malignancies may develop. ${ }^{7}$ High incidence of pruritic papular rash in this study more than seborrhoeic dermatitis is an interesting finding of this study. ${ }^{8}$ This appears to be related to the geography of the place of this study as well as due to high number of patients being farmers or agricultural labourers, since insect bite reaction is one of the important causes for pruritic papular rash in HIV.

\section{CONCLUSION}

The findings of our study were concurrent with those of previously reported studies.2,8.9 Opportunistic infections and inflammatory dermatoses of progressively increasing severe nature were seen with advanced stages of HIV infection. Opportunistic malignancies were not seen. Pruritic papular rash was the commonest finding owing to most patients being farmers by occupation. ${ }^{10}$

Early diagnosis of HIV infection is important not only for effective treatment of the affected patient but also for prevention of further transmission to others. Cutaneous manifestations can be an early pointer to this infection and hence play an important role in the control of HIV/AIDS. They are also useful for clinical staging (WHO staging) of these patients for therapeutic and prognostic purposes. ${ }^{1,3}$

\section{REFERENCES}

1. Joshi PL. Global and national overview of HIV/AIDS epidemic. In: Sharma VK. Sexually transmitted diseases and AIDS. New Delhi: Viva Books Private Limited, 2003;p 69-76.

2. Mendiratta V, Mittal S, Jain A, et al. Mucocutaneous manifestations in children with human immunodeficiency virus infection. Indian J Dermatol Venereol Leprol 2010;76(5):458-66.

3. Singh H, Singh P, Tiwari P, et al. HIV-infected patients and dermatological manifestations in a tertiary care hospital in the tribal (Bastar) region of Chhattisgarh, India between January 2006 and June 2008. Ann Trop Med Public Health 2010;3(2):64-7.

4. Kline MW. Oral manifestations of pediatric human immunodeficiency virus infection: a review of the literature. Pediatrics 1996;97(3):380-8.

5. Frommel D, Tekle-Haimanot R, Verdier M, et al. HIV infection and leprosy: a four-year survey in Ethiopia. Lancet 1994;344(8916):165-6.

6. Bosamiya SS. The immune reconstitution inflammatory syndrome. Indian J Dermatol 2011;56(5):476-9.

7. Jindal N, Aggarwal A, Kaur S. HIV seroprevalence and HIV associated dermatoses among patients presenting with skin and mucocutaneous disorders. Indian J Dermatol Venereol Leprol 2009;75(3):283-6.

8. Kore SD, Kanwar AJ, Vinay $\mathrm{K}$, et al. Pattern of mucocutaneous manifestations in human immunodeficiency virus-positive patients in North India. Indian J Sex Transm Dis 2013;34(1):19-24.

9. Chawhan SM, Bhat DM. Solanke SM. Dermatological manifestations in human immunodeficiency virus infected patients: morphological spectrum with CD4 correlation. Indian J Sex Transm Dis 2013;34(2):89-94.

10. Annam V, Yelikar BR, Inamadar AC, et al. Histopathological study of pruritic papular eruptions in HIV-infected patients in relationship with CD4, CD8 counts. Indian J Pathol Microbiol 2009;52(3):321-4. 